\title{
ROMAN SEXUALITIES
}




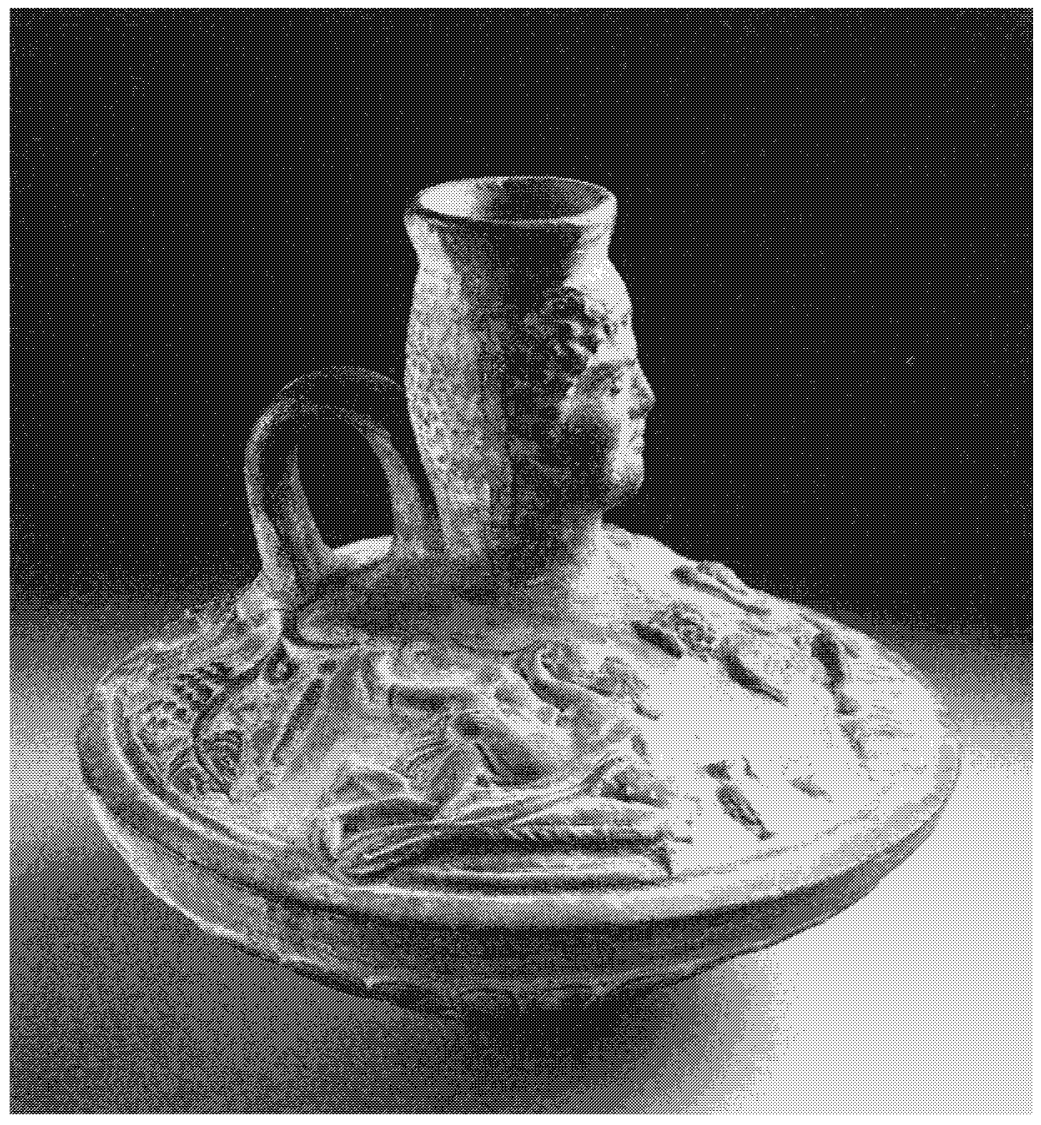

Photograph of Lagynos, Roman, late first-second century A.D. The Art Museum, Princeton University. Bequest of Professor Albert Mathias Friend, Jr. Photo Credit: Bruce M. White. 


\title{
ROMAN SEXUALITIES
}

\author{
Edited by \\ fudith P. Hallett and \\ Marilyn B. Skinner
}

PRINGETON UNIVERSITY PRESS

PRINCETON, NEW JERSEY 


\section{COPYRIGHT @ 1997 BY PRINCETON UNIVERSITY PRESS}

PUBLISHED BY PRINCETON UNIVERSITY PRESS, 41 WILLIAM STREET, PRINCETON, NEW JERSEY 08540

IN THE UNITED KINGDOM: PRINCETON UNIVERSITY PRESS, CHICHESTER, WEST SUSSEX ALL RIGHTS RESERVED

LIBRARY OF CONGRESS CATALOGING-IN-PUBLICATION DATA ROMAN SEXUALITIES / EDITED BY JUDITH P. HALLETT AND MARILYN B. SKINNER.

P. $\mathrm{CM}$.

INCLUDES BIBLIOGRAPHICAL REFERENCES AND INDEX. ISBN 0-691-01179-6 (CL : ALK. PAPER) ISBN 0-691-01178-8 (PBK. : ALK. PAPER) 1. SEX CUSTOMS-ROME-HISTORY. 2. SEX IN LITERATURE.

3. ROME IN LITERATURE. 4. CLASSICAL LITERATURE.

5. FEMINIST CRITICISM. 6. ROME-HISTORY.

7. ROME--SOCIAL LIFE AND CUSTOMS.

I. HALLETT, JUDITH P., 1944 - . II. SKINNER, MARILYN B. HQ13.R65 $1998 \quad 306.7^{\prime} 0945^{\prime} 63--D C 21 \quad 97-12684$ CIP

THIS BOOK HAS BEEN COMPOSED IN JANSON

PRINCETON UNIVERSITY PRESS BOOKS ARE PRINTED ON ACID-FREE PAPER AND MEET THE GUIDELINES FOR PERMANENCE AND DURABILITY OF THE COMMITTEE ON PRODUCTION GUTDELINES FOR BOOK LONGEVITY

OF THE COUNCIL ON LIBRARY RESOURCES

HTTP://PUP.PRINCETON.EDU

PRINTED IN THE UNITED STATES OF AMERICA

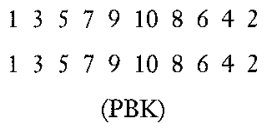


IN MEMORY OF

\title{
Fobn Patrick Sullivan
}

\author{
WHOSE SCHOLARLY CONTRIBUTIONS TO THE STUDY \\ OF ROMAN SEX AND GENDER SYSTEMS PAVED \\ THE WAY FOR THIS COLLECTION
}

vitam quae faciant beatiorem,
iucundissime Martialis, haec sunt ...
prudens simplicitas, pares amici;
convictus facilis, sine arte mensa...
quod sis, esse velis nihilque malis;
summum nec metuas diem nec optes.

(Martial 10.47) 
